U.D.C. 661.97 .074

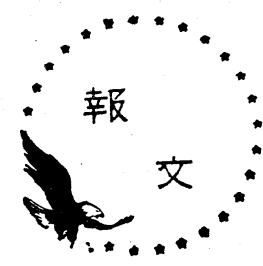

\title{
接触酸化脱硫法による炭酸ガス精製法(III)
}

一一実装置の建設および操業成績

一一昭和 36 年 2 月 3 日-

別府化学工業株式会社 村 山 和 雄

要旨：一炭酸ガスの脱硫，特にイオウ分の多い原油を用いて加圧油ガス化を行ない，脱硫す ることなく，一酸化炭素変成後回収した炭酸ガスの脱硫に用いる目的で，接触酸化脱硫法を研 究し, 第 1 報には触媒について, 第 2 報には酸化後のガスの精製および亜硫酸ガスの回収につ いてのベた。本報に㧍いては装置用材料の窝蝕試験, 実装置の建設および操業実績について簡 単にのべる。実装置にて得られた成績は甚だ優秀で, 硫化水素 $18 \mathrm{~g} / \mathrm{m}^{3}$ を含む炭酸ガスは 99.8 $\%$ の硫化水素転化率，99.5\%の亜硫酸ガス回収率を示し，装置出口ガス中の硫化水素 2 3mg $/ \mathrm{m}^{3}$ 硫化カルボニル $7 \sim 15 \mathrm{mg} / \mathrm{m}^{3}$, 亜硫酸ガス $0.1 \mathrm{mg} / \mathrm{m}^{3}$ 以下でめつた。

\section{I 脱硫装置用材料}

原料ガスおよび酸化ガスは共に酸性で水分を含むか ら腐蝕性が大きいものと想像されたが，第 1 報の触媒 活性長期試験の際同時にテストピースを插入して行な つた腐蝕試験の結果は予想に反して腐蝕は少く, 酸化 器, 水洗塔, ソーダ塔は普通鋼で十分であり, 亜硫安 液に接する塔, 配管類およびイオウ水洗塔はステンレ ススチール，鉛，アルミニウムまたは塩化ビニールを 用いればよいことがわかつた。

ステンレススチール材料の JIS に記載の腐蝕試験 法による結果は, 酸化器関係では普通銅の腐蝕减量は, $-0.5 \mathrm{~g} / \mathrm{m}^{2} \cdot \mathrm{hr}$ （この場合は増量となる）以下であ り, 亜硫安液関係では SUS 32，33，27，29 0.004 $\mathrm{g} / \mathrm{m}^{2}$. hr 以下, 鉛は $0.02 \mathrm{~g} / \mathrm{m}^{2} \cdot \mathrm{hr}$ 以下, アルミニウ 厶注 $0.04 \mathrm{~g} / \mathrm{m}^{2} \cdot \mathrm{hr}$ 以下であり, 最も腐蝕の多かつた のは酸化器後にテスト用に設けた凝縮器で, SUS 32, $33,27,29$ は $0.03 \mathrm{~g} / \mathrm{m}^{2} \cdot \mathrm{hr}$ 以下, 鉛は $1 \mathrm{~g} / \mathrm{m}^{2} \cdot \mathrm{hr}$ 以 下，アルミニウムは $0.2 \mathrm{~g} / \mathrm{m}^{2} . \mathrm{hr}$ 以下であつた。実 装置の酸化器後のイオウ水洗塔は温度が低いからこれ より若干腐蝕性は少いと思われる。酸化器に SUS 23 (13クロム鋼) を用いた結果は $0.007 \mathrm{~g} / \mathrm{m}^{2} \cdot \mathrm{hr}$ 以下で むつた。

\section{II 実装置の建設および操業成績}

第 1 報および第 2 報にのべた研究結果㧍よびIの材
料試験結果に基づいて硫化水素 1 2\% (15 30 $\left.\mathrm{g} / \mathrm{m}^{3}\right)$

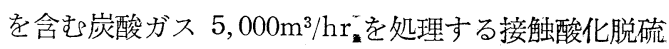
装置を設計建設した。

原料ガスは別府化学のテキサコ式加圧油ガス化炉を 用いた 100t/日 能力を有するアンモニア合成工場より 発生する炭酸ガスである。すなわちイオウ分2.4 2.6 \%のクエート原油をテキサコ炉の原料油とし，脱硫す ることなく一酸化炭素変成を行ない，熱炭酸カリおよ びモノェタノールアミン吸収塔にて脱炭酸後再生した 炭酸ガスは, 1.1〜1.2\%の硫化水素を含み，ガス組成 の一例は $\mathrm{CO}_{2} 97.7 \%, \mathrm{H}_{2} \mathrm{~S} 1.2 \%\left(18.2 \mathrm{~g} / \mathrm{m}^{3}\right), \mathrm{O}_{2} 0.1$ $\%, \mathrm{CO} 0.1 \%, \mathrm{H}_{2} 0.9 \%, \operatorname{COS} 2 \sim 2.5 \mathrm{Smg} / \mathrm{m}^{3}$ で あつた。この粗炭酸ガス $4,000 \mathrm{~m}^{3} / \mathrm{hr}$ に約 $100 \mathrm{~m}^{3} / \mathrm{hr}$ の酸素を添加し $410 \sim 450^{\circ} \mathrm{C}$ で酸化触媒に通じたとこ 万, 酸化器出口ガス中の $\mathrm{H}_{2} \mathrm{~S} \quad 20 \sim 40 \mathrm{mg} / \mathrm{m}^{3}, \quad \mathrm{SO}_{2}$ $34 \mathrm{~g} / \mathrm{m}^{3}$ であつた。第 1 亜硫酸ガス回収塔後では $\mathrm{SO}_{2}$ $4.3 \mathrm{~g} / \mathrm{m}^{3}$ で $\mathrm{SO}_{2}$ 除去率 $87.6 \%$ ，第 2 亜硫酸ガス回収 塔後では $\mathrm{SO}_{2} 190 \mathrm{mg} / \mathrm{m}^{3}$ で $\mathrm{SO}_{2}$ 除去率は合せて 99 $.5 \%$ ，水洗塔後では $\mathrm{SO}_{2} \quad 0.5 \mathrm{mg} / \mathrm{m}^{3}$ で $\mathrm{SO}_{2}$ 除去率 は99. 9985\%,ソーダ塔後ではガス組成は $\mathrm{CO}_{2} 99.2 \%$ ， $\mathrm{O}_{2} 0.1 \sim 0.2 \%, \mathrm{CO} 0.1 \%, \mathrm{H}_{2} 0.5 \%, \mathrm{H}_{2} \mathrm{~S} 2 \sim 3 \mathrm{mg}$ $/ \mathrm{m}^{3}$, COS $7 \sim 15 \mathrm{Smg} / \mathrm{m}^{3}, \mathrm{SO}_{2} 0.1 \mathrm{mg} / \mathrm{m}^{3}$ 以下であ つた。第 1 亜硫酸ガス回收塔の循環液は 比重 1.15 , $\mathrm{pH} 4.9$, 第 2 亜硫酸ガス回収塔の循環液は比重 1.15 , 
接触酸化脱硫裝置系統困

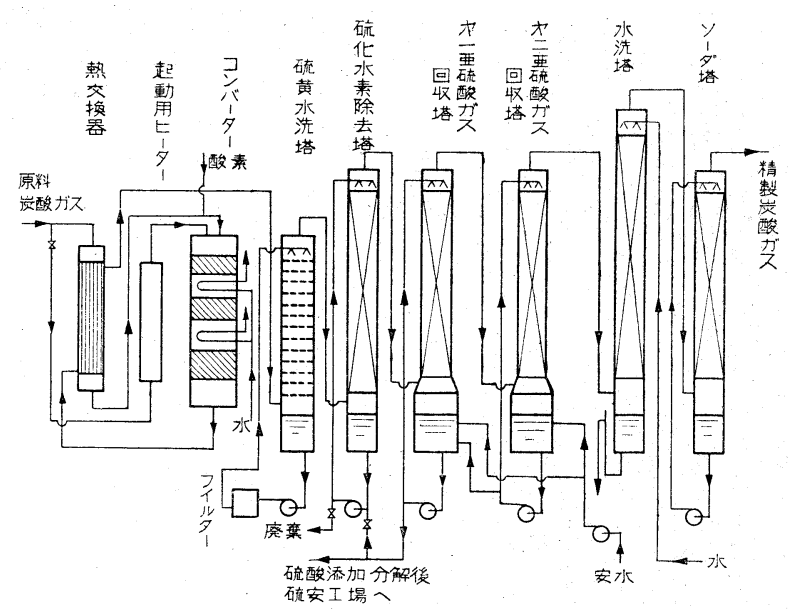

$\mathrm{pH} 6$ であつた。な打水洗塔は海水を，ソーダ塔は $3 \%$ 炭酸ソーダ水溶液を用いた。

脱硫後のガスは小型の乾式脱硫打よび有機脱硫に通 じて容易に全イオウ $1 \mathrm{mg} / \mathrm{m}^{3}$ 以下とすることができた。 つぎに本法による接鳋酸化脱硫装置の系統図をかか げる。この系統図はイオウ水洗塔, 硫化水素除去塔を も有するもので, 亜硫酸ガス回収液の腐蝕性防止に特 に留意したものである。また装置出口ガス中の 0.1 $0.2 \%$ の酸素をさらに呧下したいときは上記有機脱硫 後に水素然焼用の酸化器をおけばよい。

\section{III 結語}

テキサコ法のような加圧油ガス化法は今後ますます
盛に採用されるものと思われるが，イオウ分の多い中 東原油を原料油とし，脱硫することなく一酸化炭素変 成を行ならときは，原料油中のイオウ分はほとんどす ベて回収炭酸ガス中に入り，この炭酸ガスの脱硫，イ オウ分回収の問題は重要となつてくる。

ここに報告した接触酸化脱硫法は硫安工場が併置さ れている限り実施容易で, 硫化水素の酸化率 99.8〜 99.9\%，イオウ分の亜硫酸ガスとしての回収率 $99.5 \%$ 以上で, 精製ガスは純度高く, 脱硫操業費は低廉であ り, 実装置の操業実績にみるとおり優れた性能を示し ている。

\title{
Purification of Carbon Dioxide through Desufurization by Catalytic Oxidation (III)
}

\author{
by Kazuo Murayama
}

(Befu Chemical Co. Ltd.)

SYNOPSIS : - For the desulfurization of carbon dioxide, catalytic oxidation process was found very useful. In the 1 st report catalysts and oxidation conditions were presented, and in the 2nd report purification of oxidzed gas and recovery of $\mathrm{SO}_{2}$ were described.

In this report corrosion data on fabricating material and operation data of actual unit are reported.

Author designed and constructed a plant having the capacity of $5,000 \mathrm{Nm}^{3} / \mathrm{hr}$, and has put it into successful operation. For example, $4,000 \mathrm{Nm}^{3} / \mathrm{hr}$ raw $\mathrm{CO}_{2}$ from hot carbonate and MEA unit having the following composition, $\mathrm{CO}_{2} 97.7 \%, \mathrm{H}_{2} \mathrm{~S} 1.2 \%, \mathrm{O}_{2} 0.1 \%, \mathrm{CO}$ $0.1 \%, \mathrm{H}_{2} 0.9 \%$ and Org.S $2 \sim 2.5 \mathrm{Smg} / \mathrm{m}^{3}$, was desulfurized by this process, and the composition of the desulfurized $\mathrm{CO}_{2}$ was as follows, $\mathrm{CO}_{2} 99.2 \%, \mathrm{O}_{2} 0.1 \sim 0.2 \%$, $\mathrm{CO} 0.1 \%$, $\mathrm{H}_{2} \quad 0.5 \%, \mathrm{H}_{2} \mathrm{~S} 2 \sim 3 \mathrm{mg} / \mathrm{m}^{3}$, Org. S $7 \sim 15 \mathrm{Smg} / \mathrm{m}^{3}$ and $\mathrm{SO}_{2} 0.1 \mathrm{mg} / \mathrm{m}^{3}>$. 